Pamiętnik Literacki 2013, 4, s. 115-134
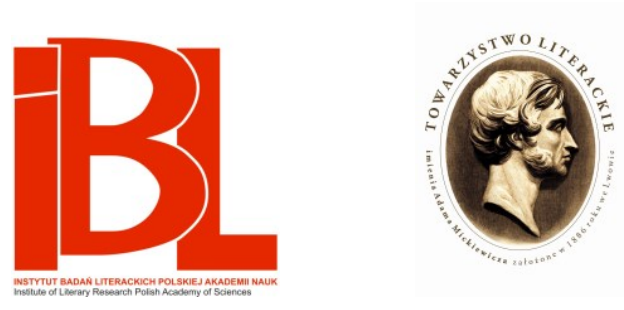

\title{
Georges Perec i praca żałoby
}

Paweł Jasnowski 


\section{GEORGES PEREC I PRACA ŻAŁOBY}

język zaczyna się od n e g a c j i (Verneinung) utraty i tym samym negacji depresji spowodowanej żałobą. Byt mówiący wydaje się głosić: ,Straciłem najważniejszy obiekt, który ostatecznie okazał się moją matką. Ależ nie, odnalazłem ją w znakach, albo raczej nie utraciłem jej (oto negacja) i mogę ją odzyskać w języku [...]”. $[\mathrm{K} 49]^{1}$

Piszę, ponieważ zostawali we mnie niezatarty ślad, ponieważ ów ślad utrwalony jest w moim pisaniu; [...] pisanie jest wspominaniem ich śmierci i afirmacją mojego życia. [W 63-64]

Dla Szymona J.

\section{Układanie puzzli. Wprowadzenie}

W przenikliwym wstępie do pism Julii Kristevej Michał Paweł Markowski rozrysował opozycję ukazującą dwie odmienne, wzajemnie się wykluczające koncepcje zadań nauk humanistycznych. Na jednym biegunie umieścił Wilhelma Diltheya oraz jego przekonanie, że muszą one wychodzić poza to, co idiomatyczne i przygodne, kładąc akcent na tym, co obiektywne; na przeciwległym biegunie zaś Kristevą, przypisującą owym naukom rolę zgłębiania tego, co jednostkowe i przekraczające przestrzeń obiektywnego postrzegania ${ }^{2}$. Zgodnie z Diltheyowskim założeniem żadne wielkie dzieło sztuki nie może „pozorować obcej swemu autorowi treści duchowej”, co więcej, „,nie pragnie ono nawet mówić niczego o autorze" "3. I choć niemiecki filozof wie, że u źródeł dzieła sztuki kryje się zawsze swoiste podmiotowe doświadczenie, to programowo z niego rezygnuje, odmawiając mu znaczenia. Dithleya bowiem interesuje wyłącznie skończone dzieło, a nie

1 Skrótem K oznaczam cytaty z książki: J. K r i s te v a, Czarne słońce. Depresja i melancholia. Przeł. M. P. Mark ow s ki, R. Ry ziń s ki. Wstęp M. P. Mark ow s ki. Kraków 2007. Poza tym w rozprawie posługuję się następującymi skrótami: $\mathrm{B}=\mathrm{D}$. B e 11 o s, Georges Perec. Une vie dans les mots. Paris 1994. - C = G. P e r e c, Człowiek, który śpi. Przeł. A. W a s i l e w s k a. Kraków 2011. - W = G. P e re c, $W$ ou le souvenir d'enfance. Paris 2012. Liczby po skrótach wskazują numery stronic.

2 M. P. Markowski, Przygoda ciała i znaków. Wprowadzenie do pism Julii Kristevej. W: K XLIII-XXIV.

3 W. Dil the y, Budowa świata historycznego w naukach humanistycznych. Przeł., oprac., posł. E. P a c z k ow s k a - Ł a g o w s ka. Gdańsk 2004, s. 192-193. 
proces, który je umożliwił. Kristeva przeciwnie, jednostkowe doświadczenie czyni obiektem nieustannego namysłu. Czytelnik, miast przyjmować dzieło za gotowe i zamknięte, powinien próbować wydobyć z jego wnętrza owo doświadczenie. Kristeva uważa bowiem, iż dzieła są ,podmiotowymi manifestacjami, że są nie tyle wytworami procesu, co samym procesem, nie tyle artefaktem, co d oś wi a d c ze n i e m"4. W ujęciu badaczki tekst nie tylko mówi o swym autorze, ale też wpływa na dyskurs podmiotu i na sam podmiot, ujawniając - wbrew temu, czego oczekiwał Dilthey -,obcą autorowi treść”, to, czego on sam o sobie nie wie.

Przyglądając się dziełu Georges'a Pereca i namysłowi, jakiemu poddawał on akt pisania, łatwo zauważyć, że rola, jaką wyznaczał literaturze, harmonizuje z tym samym dyskursem, którym posługuje się niezmiennie Kristeva - reprezentująca, naturalnie, niemałą część humanistów, z pewnością zaś spadkobierców Freuda, niezależnie od tego, jak dalece zreinterpretowali oni jego dzieło.

Oto bowiem, co Perec mówi w szkicu Uwagi o tym, czego szukam:

Moje kolejne książki utwierdzają mnie w przekonaniu, czasem pokrzepiającym, a czasem niewygodnym (bo zawsze w zawieszeniu, aż do „przyszłej książki”, niedokończonego dzieła oznaczającego ,niewypowiedziane”, ku czemu desperacko zmierza pragnienie pisania), że przemierzają one pewną drogę, zawłaszczają pewien obszar, wytyczają po omacku pewien szlak, opisując punkt po punkcie etapy mojego poszukiwania $[\ldots]^{5}$.

Nie ulega wątpliwości, że dla tego pisarza jego kolejne powieści nie byłby gotowymi artefaktami, ale wytworami procesu, dziełami nie zamkniętymi raz na zawsze, lecz noszącymi w sobie to, co w psychoanalitycznym dyskursie zwykło się nazywać językiem nieświadomości; że, ujmując rzecz jeszcze inaczej: są one tekstami, gdzie osadzają się treści, które odpowiadają na wezwanie wyrażone w greckiej sentencji „Gnothi seauton”, powtarzanej z upodobaniem przez Pereca ${ }^{6}$. Co więcej, wierzył on, że jego książki - nie tylko każda z osobna, ale i wszystkie razem - tworzą pewien wzór, nabierają sensu, stanowiąc rozrzucone kawałki układanki kiedyś przedstawią obraz jak ,nieubłaganie ukończone puzzle" ${ }^{\text {. Znamien- }}$ ne, że tą samą metaforą i rozpoznaniem Perec posłuży się, pisząc o procesie psychoterapii, którą powtarzał wielokrotnie, przez całe życie zmagając się z dziecięcą traumą i pustką po śmierci rodziców:

Kiedy [w czasie terapii] usiłowałem mówić, [...] natychmiast miałem wrażenie, że byłem $\mathrm{w}$ trakcie rozpoczynania tych samych puzzli, jakbym w ten sposób dzięki stopniowemu wyczerpaniu się wszystkich możliwych kombinacji, mógł w końcu pewnego dnia ułożyć obraz, którego szukałem ${ }^{8}$.

Podążając za rozpoznaniem, że literatura odsłania nam idiomatyczne doświadczenie podmiotu, i za postulatem, by to samo czyniła nauka o literaturze - przynosząc nam wiedzę o naszej podmiotowości - w niniejszym szkicu śledzę psychoanalityczne tropy, które występują w życiu i dziele Pereca. Pytam przede wszystkim

4 Markowski, op. cit., s. XXXVIII.

5 G. P e r e c, Uwagi o tym, czego szukam. W: Urodziłem się. Eseje. Red. J. Olczyk. Kraków 2012, s. 12 (przeł. M. Ławnic zak).

${ }_{6}$ Gr. Gnothi seauton - poznaj samego siebie. Zob. G. P e r e c, Jesienne gnocchi albo odpowiedź na kilka dotyczacych mnie pytań. W: Urodzitem się. Eseje, s. 193 (przeł. E. K u n i e c).

7 P e r e c, Uwagi o tym, czego szukam, s. 12.

8 G. P e r e c, Miejsca pewnego podstępu. W: Urodzitem się. Eseje, s. 43 (przeł. J. O 1 c z y k). 
o relację między doświadczeniem pustki a tworzeniem i o status żałoby pisarza, w której często widziano znak negacji ${ }^{9}$.

\section{Zniknięcie}

Georges Perec urodził się w Paryżu w marcu 1936 i pierwsze lata swojego życia spędził w XX dzielnicy przy ulicy Vilin, gdzie pod numerem 24 mieścił się mały salon fryzjerski jego matki, Cécile (Cyrli) Perec, a pod numerem 1 dom dziadków Szulewiczów ${ }^{10}$, którzy, podobnie jak Perecowie - rodzina André (Icka), ojca przyszłego pisarza - osiedlili się w Paryżu w latach międzywojennych. Choć wczesne dzieciństwo upływało w cieniu trosk o przyszłość, niepewności i zmartwień, to dla samego Pereca było bez wątpienia okresem prawdziwego szczęścia. Jednym z niewielu wspomnień ${ }^{11}$, które $\mathrm{z}$ tego czasu zachował i utrwalił w powieści $W$ ou le souvenir d'enfance, jest scena w rodzinnym salonie. Georges ma wtedy trzy lata, siedzi na podłodze, pośród rozrzuconych wokół żydowskich gazet. Otaczają go najbliżsi, śledzący uważnie jego ruchy; ostatni raz, być może, zaznaje wtedy opieki, ciepła i miłości. Po chwili wszyscy uśmiechają się szeroko: chłopiec zakreśla pierwszą w życiu literę alfabetu hebrajskiego ${ }^{12}$.

$Z$ relacji ciotki Esther dowie się Perec, że jeszcze przed wojną chodził z młodszą ciotką, Fanny, na spacery, podczas których do jego ulubionych zabaw należało odszyfrowywanie liter w lokalnych dziennikach; nie były to jednak bynajmniej litery hebrajskiego alfabetu, ta zaś postawiona wtedy w salonie rodzinnym, stanowiła zarazem jego ostatnią literę w tym języku. W przeciwieństwie do swoich rodziców, którzy urodzili się w Polsce (w Lubartowie i Warszawie), Perec przyszedł na świat w Paryżu, został zarejestrowany jako rodowity Francuz i pozostał nim $\mathrm{w}$ istocie przez całe życie ${ }^{13}$.

Z krótkiego, nieledwie zapomnianego dzieciństwa spędzonego w domu przy ulicy Vilin przechowa Perec jeszcze dwa niepewne, pokryte patyną lat wspomnienia:

miałem w zwyczaju przychodzić rano do łóżka rodziców; matka wstawała, ale ojciec, który zdążył już wrócić z Les Halles, nadal spał. Moja ulubiona zabawa polegała na daniu nura pod pościel i przeczołganiu się do jego stóp, które łaskotałem, wybuchając raz po raz śmiechem ${ }^{14}$.

9 To zaś nierozerwalnie wiąże się z pytaniem, czy inkorporacja (wraz z odmową żałoby), o której pisali N. Abraham i M. Török, jest rzeczywiście jedynym możliwym kluczem do zrozumienia dzieła Pereca - jak sugerował M. P. M a rk o w s k i (Perekreacja. W: G. P e r e c, Gabinet kolekcjonera. Historia pewnego obrazu. Przeł. M. P. M a rk ow s k i. / M. P. M a rkow s k i, Perekreacja. Warszawa 2003).

${ }_{10}$ Zob. B 55.

11 Jest to, według słów Pereca, jego pierwsze wspomnienie z dzieciństwa. W rzeczywistości w przechowanych przez niego zamkniętych kopertach, zawierających m.in. notatki na temat ulicy Vilin, znajdują się inne reminiscencje, wcześniejsze w stosunku do tej dotyczącej pierwszej litery zapisanej w języku hebrajskim.

${ }^{12}$ Zob. W 26-27.

13 Problem tożsamości pisarza, zwłaszcza zaś jego stosunek do dziedzictwa żydowskiego, które nie zostało mu przekazane, wykracza poza ramy niniejszego studium i domaga się osobnego ujęcia. O stosunku Pereca do żydowskości zob. m.in. M. B é n a b o u, Perec et la Judéité. Red. B. Magné. Paris 1985, s. 15-30.

${ }_{14}$ D. B e 11 o s, Życie w słowach. Przeł. J. K o z i o ł. „Literatura na Świecie” 1995, nr 11/12, s. 312 . 
Kolejne wspomnienie, które zapisze potem $\mathrm{w}$ powieści $W$ ou le souvenir d'enfance, jest krótsze,

przypomina bardziej sen; wydaje się ono jeszcze bardziej skonfabulowane niż pierwsze, istnieje w kilku wariantach [...]. Jego najprostszy obraz byłby taki: mój ojciec wraca z pracy; i daje mi klucz. W pierwszym wariancie klucz jest złoty; w innym nie jest to w ogóle złoty klucz, ale złota moneta. [W 27]

W niedługi czas później ów „niezwyciężony”, ochronny mur, jakim otaczali małego Georges'a rodzice, przejęci wnukiem dziadkowie i krewni, pęknie i runie, zostawiając wyrwę, pustkę i dziurę, zapisaną zresztą - jak zauważał sam Perec - już w biblijnym źródłosłowie jego nazwiska: פרצ, którego hebrajski ,szoresz” (korzeń) to właśnie: 'dziura', francuskie ,le trou" (słowo wielokrotnie powracające w dziele Pereca) ${ }^{15}$. W dniu zawieszenia broni, w lipcu 1940, ojciec przyszłego autora $W$ ou le souvenir d'enfance zostaje przypadkowo postrzelony w brzuch na froncie w Nogent-sur-Seine. Szpital pęka w szwach. Icek, André Perec „ginie śmiercią niedorzeczną i powolną” (W 48). Mama natomiast - pisze Perec -

została zatrzymana w czasie łapanki ze swoją siostrą, moją ciocią. Została internowana [w obozie przejściowym] w Drancy 23 stycznia 1943, a następnie, 11 lutego, wysłana do Auschwitz.

Przed śmiercią wróciła do kraju swojego urodzenia. Umarła, nie rozumiejąc. [W 53]

To właśnie wtedy formuje się podstawowe w życiu Pereca doświadczenie pustki; śmierć rodziców, śmierć matki odbiera mu trwałą pozycję w świecie, jest czymś, co „wyrzuca go z siodła”, pozbawia punktu zaczepienia, jest czymś obezwładniającym, piekącą raną, która będzie dawać o sobie znać przez całe życie.

\section{Epoka W}

Perec miał 6 lat w chwili rozłąki z matką na dworcu w Lyonie, skąd odjechał z konwojem Czerwonego Krzyża. Pociągiem dotarł do Villard-de-Lans (w okolicy Grenoble, w regionie Rhône-Alpes), gdzie mieszkała rodzina męża jego ciotki Esther, Davida Bienenfelda i gdzie w niewielkiej odległości od centrum mieścił się katolicki collège Turenne (,Le Clocher"), do którego posłano Pereca. Jego egzystencję od tego momentu cechował przede wszystkim brak punktu orientacyjnego i punktu wyjścia. Ocalone wspomnienia pozostawały rozdarte i jak gdyby zawieszone w próżni, nic ich nie wiązało ani nie potwierdzało: „Nie było ani początku, ani końca. Nie było już przeszłości, a przez dłuższy czas nie było też przyszłości” (W 98). Sięgając pamięcią do pobytu w Villard-de-Lans w quasi-autobiograficznym $W$ ou le souvenir d'enfance (W albo wspomnienie z dzieciństwa), Perec napisze:

wolałbym pomagać matce w sprzątaniu kuchennego stołu po kolacji. Byłaby na nim cerata $\mathrm{z}$ niebieskimi, drobnymi kwadratami. Nad stołem wisiałby żyrandol $\mathrm{z}$ abażurem $\mathrm{w}$ formie nieomal talerza; biała porcelana, emaliowane blachy [...]. Potem poszukałbym mojego tornistra, wyciągnąłbym książkę, moje zeszyty i drewniany ołówek, położyłbym je na stole i zaczął odrabiać lekcje. Tak, jak to się działo na kartach moich podręczników. [W 99]

Perec, który po powrocie do Paryża w połowie 1945 roku zamieszkał z siostrą

15 Zob. W 56. Szerzej o tym B 23-28. Zagadnieniu temu poświęcił miejsce także M a rkow ski (Perekreacja). 
ojca, Esther, i jej mężem przy ulicy l’Assomption, odnalazł tam, z jednej strony, troskę okazywaną przez ciotkę, przejętą jego losem, z drugiej, żelazną rękę wuja, niezdolnego do wyrażania uczuć, który wszakże włączył się w wychowanie 9-letniego Georges'a. Bardzo szybko, bo już w 2 lata po wojnie, Perec przestał być jednak najważniejszym dzieckiem w domu, w tym bowiem czasie u Bienenfeldów zamieszkała ich wnuczka, Marianne ${ }^{16}$.

Choć nie sposób, oczywiście, dokładnie odtworzyć życia emocjonalnego pisarza w okresie powojennym (co wykracza poza ramy tego studium), to cała pewnością można stwierdzić, że pozostawało ono w rozsypce. „Nie przychodził, kiedy się go wołało, zasiadał ociężale przy stole, odmawiał zakładania serwety, odpowiadał grubiańsko", a do ciotki żywił falę ciemnych uczuć i urazów dlatego przede wszystkim, ,że nie nazywała się Cécile, ale Esther” (B 115). Pewnego dnia, mając nie więcej niż 12 lat, postanowił nie wrócić do domu po szkole i włóczył się po mieście. Ostatecznie, znaleziony przez rodzinę na Polach Elizejskich, siedział na ławce przemarznięty, głodny i samotny ${ }^{17}$.

Od początku najsilniejsza więź łączyła go ze starszą o 9 lat kuzynką Elą (Lili), która pozostawała blisko pisarza aż do jego śmierci. To właśnie ona skontaktowała się z dyrektorem Centre Claude-Bernard, dokąd po wojnie uczęszczał Perec, zaniepokojona zachowaniem się kuzyna i jego rysunkami, które sam pisarz wspomina tak:

w epoce W, między - powiedzmy - jedenastym a piętnastym rokiem życia pokrywałem [nimi] całe zeszyty. Postaci, których nic nie wiązało z ziemią, okręty, których skrzydła nie trzymały się masztu ani kadłuba, maszyny wojenne, maszyny śmierci, samoloty, pojazdy o niewiarygodnych mechanizmach, ze swoimi rozłączonymi dyszami, przerwanymi linami, kołami obracającymi się w pustce; skrzydła samolotów nie związane z kadłubem, nogi atletów i ramiona nie przytwierdzone do tułowia [...]. [W 97]

Perec został wówczas po raz pierwszy poddany psychoterapii, prowadzonej przez Françoise Dolto, która w roku 1953, po wykluczeniu Jacques'a Lacana z Międzynarodowego Stowarzyszenia Psychoanalitycznego ${ }^{18}$, założyła wraz z nim, Danielem Lagache'em i Juliette Favez Boutonnier - Société française de psychanalyse ${ }^{19}$.

Dolto, do której na ulicę Saint-Jacques udawał się Georges raz w tygodniu (przynajmniej przez rok) czerpała m.in. z dorobku freudystki Mélanie Klein i Anny Freud, wypracowując własną metodę terapeutyczną polegającą na ,analizie języka dzieci, wyrażającego się nie tylko w mowie, lecz również i przede wszystkim w rysunku i w modelach z plasteliny" ${ }^{20}$. Ów cykl seansów, podobnie jak terapia podjęta niecałe 10 lat później (z Michelem de M’Uzanem) i wreszcie 4-letnia

16 Zob. B 113.

17 Zob. ibidem, s. 118-121.

${ }_{18}$ Międzynarodowego Stowarzyszenie Psychoanalityczne zostało założone przez psychoanalityków, w tym S. Freuda, w roku 1910.

19 Dolto zakładała także wraz z Lacanem w 1964 roku l'École Freudienne de Paris. Oboje czuli się twórcami freudyzmu francuskiego. Jak niedawno napisano w setną rocznicę urodzin Dolto, jest ona ciągle jedną z najpopularniejszych we Francji postaci w historii psychoanalizy.

20 A. R z e c z y c k a, Setna rocznica urodzin Françoise Dolto. Na stronie internetowej: http:// www.rfi.fr/actupl/articles/107/article_6088.asp (data dostępu: 22 VII 2013). 
psychoanaliza z Jeanem-Bertrandem Pontalisem, okazały się - jak się przekonamy - przełomowe nie tylko dla życia, ale także dla dzieła Pereca.

\section{Życie odwołane}

Bez wątpienia momentem zwrotnym dla Pereca był rok 1956 i 1957. W styczniu 1956, kończąc 20 lat, miał on już przepisaną na maszynie powieść Les Errants; zaszyfrowany ślad po niej pozostał w opublikowanej u schyłku życia książce Życie, instrukcja obsługi ${ }^{21}$. Był to tekst, do którego Perec przywiązywał ogromną wagę, swego rodzaju manifest jego chęci pozostania pisarzem. Ciotka Esther Bienenfeld, przestraszona tym pomysłem, zwróciła się wówczas o radę do Jeana Duvignauda, nauczyciela Pereca i kogoś w rodzaju jego duchowego przewodnika. Miał on ją uspokoić, prosząc o ,zaufanie chłopcu i danie mu szansy” (B 149). Jednak to właśnie Duvignaud i Jacques Lederer - pianista i znawca jazzu ${ }^{22}$, z którym Georges zaprzyjaźnił się w okresie edukacji w collège Geoffroy-Saint-Hilare d'Étampes - bardzo ostro skrytykowali wkrótce Perecowski debiut ${ }^{23}$.

W tym czasie Perec poczuł, że życie zaczyna mu się wymykać z rąk, że coś niepokojąco pęka, że zaczyna w nim wzrastać uczucie pustki, które dotąd zdawało się pozostawać uśpione, pozwalając mu żyć normalnie. To właśnie w tym roku odwiedził po raz pierwszy grób swojego ojca w Nogent-sur-Seine i zapisał na odwrocie jego jedynego zdjęcia - które obok fotografii matki leżało stale u wezgłowia łóżka Pereca w domu przy ulicy l'Assomption - bardzo krótkie, choć zostawiające znaczący trop zdanie: „Il y a quelque chose de pourri dans le royaume de Danemark” (W 45; co można przetłumaczyć jako: „Jest coś zgniłego w Królestwie Danii"). Znamienne, zwłaszcza w kontekście tych słów, będących bez wątpienia aluzją do Szekspirowskiego Hamleta, było samooskarżenie, które Perec wielokrotnie i z nieomal perwersyjną pasją ponawiał: „J e s te m zły m s y n e m".

To, co Perecowi doskwierało najdotkliwiej i co doprowadziło go na skraj szaleństwa, było związane z wrażeniem własnej bezwartości, bezsilności i braku czułości. W listach, które pisał do Henriego Chavranskiego, Jeana Duvignauda i Huguette Moralès między lutym a sierpniem 1956, tak rozpoznawał swoją depresję:

W perspektywie marksistowskiej jestem bytem nieproduktywnym i niepożądanym w mojej własnej - nieudacznikiem [...]. Jestem złym synem i miernym historykiem. [B 170]

${ }^{21}$ W przedpokoju w mieszkaniu Bartlebootha troje służących „oczekuje na mało prawdopodobny dzwonek, którym wezwać ich może chlebodawca”. Jeden z nich, Kléber, zaczyna stawiać pasjansa, a obok kart „leży otwarta książka; jest to amerykańska powieść pióra George'a Bretzlee, The Wanderers, której akcja toczy się w nowojorskim środowisku jazzowym na początku lat pięćdziesiątych" (G. P e r e c, Życie, instrukcja obstugi. Przeł. W. B r z o z o w s k i. Kraków 2009, s. 153). Tytuł owej książki to, oczywiście, aluzja do Les Errants, powieści, w której Perec zawarł swoją jazzową pasję. Naturalnie, w rzeczywistości nie istnieje ani książka pt. The Wanderers, ani pisarz George Bretzlee - to z kolei nawiązanie do nazwiska autora Życia, instrukcji obstugi, które w wariancie przyjętym przez Żydów węgierskich zapisywane było „Bretzel”.

${ }_{22}$ Lederer, podobnie jak Perec, stracił jedno z rodziców w Auschwitz; pisarz pozostał z nim w bliskich relacjach aż do swojej śmierci w roku 1982.

${ }^{23}$ Zob. B 168-169. 
Nie poznałem [...] tego, co dla mnie najważniejsze, czułości: dlatego, że już na początku zostało mi to odebrane wraz ze śmiercią mojej matki. [B 170]

Przyczyna powierzchowna: samotność. Przyczyna głęboka: bezsilność. Przyczyna pierwsza: brak wiary w siebie. Przyczyna ukryta: brak czułości. [B 170]

Ostatnia z nich długo pozostawała - Perec nieprzypadkowo użył tego słowa - uk ry t a, pod powierzchnią, ale określająca wszystkie inne; przyczyna, którą w czasie terapii z M'Uzanem zaczął przepracowywać. Wyjście z milczenia, z pustki asymbolii, w jaką popadł, zawdzięczał bez wątpienia właśnie terapii. Jej ostatecznym efektem było napisanie kilka lat później m.in. Człowieka, który śpi, gdzie w przejmujący sposób utrwalił przełomowy okres, w którym: „Coś pękało, coś pękło" (C 16):

Nieszczęście [...] wsączało się pomału, wślizgiwało niemal ze słodyczą. Dogłębnie przepoiło twoje życie, twoje gesty, twój czas, twój pokój, niczym dłu g o s krywana prawda, niczym odrzucana oczywistość [...]. [C 76; podkreśl. P. J.]

\section{Alter ego autora pyta:}

Czy przez dwadzieścia pięć lat nic nie wiedziałeś o tym, co dzisiaj jest już nieubłagane? Czy w tym, co brałeś za swoją historię, nigdy nie dostrzegałeś żadnych luk? Martwych chwil, pustych przebiegów. Ukradkowych i dotkliwych pragnień, aby niczego już nie słyszeć, niczego nie widzieć, aby trwać w bezruchu i milczeniu. [C 20]

I choć Perecowski Człowiek, który śpi nie wyjawia explicite tego, czym miałaby być ,długo odrzucana rzeczywistość” (C 76), czym jest to, ,co dzisiaj jest już nieubłagane" (C 20), czym jest, inny wątek, zawsze obecny, zawsze trzymany na uboczu, który teraz wyplata znajomy wzór twojej przywróconej egzystencji” (C 21-22), to uważny czytelnik domyśla się, że chodzi o uwewnętrznioną, głęboko ukrytą i osnutą milczeniem utraconą Rzecz ${ }^{24}$ - o śmierć matki.

\section{Odmowa żałoby}

Bohater Pereca, człowiek, który pogrąża się we śnie, popada w milczenie i przegląda się w pustce (C 33), nie mogąc pogodzić się z utraconą Rzeczą, przypomina, naturalnie, figurę melancholika opisaną przez Freuda w klasycznym tekście Żałoba $i$ melancholia ${ }^{25}$, a następnie m.in. przez Kristevą, która reinterpretując Freuda i Lacana, zajęła się podmiotem depresyjnym i zaburzeniem jego symbolicznej relacji ze światem ${ }^{26}$. Podstawowe rozróżnienie na negację i odrzucenie negacji, na Verneinung i Verleugnung, wprowadzone przez Kristevą za Freudem i nieznacznie zmodyfikowane, to dwie możliwie strategie, dwie możliwe drogi podmiotu wobec niepowetowanej i nieodwracalnej utraty Rzeczy. Negację rozumie Kristeva jako: ,intelektualne działanie, które prowadzi to, co wyparte, do

$24 \mathrm{~W}$ dalszej części rozprawy posługuję się terminologią zaproponowaną przez Kristevą, zgodnie z przyjętym paradygmatem badawczym.

25 Z. Freud, Żałoba $i$ melancholia. Przeł. J. J a błoń s k a - D z i e r ż a. W zb.: Depresja: ujęcie psychoanalityczne. Red. K. Walewska, J. Pawlik. Warszawa 1992.

26 Problem ten ukazała w Czarnym słońcu, pytając jak zawsze o relację między językiem a doświadczeniem podmiotu. O dorobku Kristevej i miejscu, jakie zajmuje w nim Czarne słońce. Depresja i melancholia, zob. M a r k o w s k i, Przygoda ciała i znaków. 
przedstawienia, pod warunkiem jego odrzucenia, a w związku z tym bierze udział w pojawieniu się signifiant" (K 49).

N e g a c j a (Verneinung), której wieloznaczność Freud podtrzymuje i pogłębia w swym szkicu Die Verneinung, jest procesem, który wprowadza aspekt pragnienia oraz ideę nieświadomości do świadomości. „Wynika stąd pewien rodzaj intelektualnej akceptacji tego, co zostało wyparte, chociaż wyparcie pozostaje tym, co zasadnicze”. [K 51 $]^{27}$

W ostatecznym rozrachunku negacja, Freudowskie Verneinung, jest więc tym, co umożliwia żałobę, będącą naturalnym procesem niezbędnym dla zdrowia psychicznego podmiotu, który utracił Rzecz. Proces żałoby to, jak wiemy, w perspektywie freudowskiej chwilowe zahamowanie i ograniczenie ego, jakie po wykonaniu pracy żałoby staje się na powrót wolne i niezahamowane. Innymi słowy, znak negacji stanowi akceptację utraty, „odklejenie” się od Rzeczy, do której podmiot pozostawał rozpaczliwie przylgnięty, i jednoczesne odnalezienie jej w znakach, w języku, a więc także: w literaturze.

$\mathrm{Z}$ kolei odrzucenie negacji, Verleugnung, rozumie Kristeva jako rezygnację z signifiant oraz z semiotycznych przedstawień popędów i uczuć. Wynika z tego, że:

traumatyczne wspomnienia (utrata jednego z rodziców w dzieciństwie albo jakieś niedawne cierpienie) nie zostają wyparte, lecz są stale przywoływane, zaś odrzuce nie ne ga cji udaremnia pracę wyparcia lub co najmniej jego przedstawiającej części. Podobne do tego rodzaju ewokacji przedstawienie tego, co wyparte, nie osiąga poziomu symbolicznego o p r ac ow an i a utraty [...]. [K 52]

Podmiot, który został pozbawiony ukochanej Rzeczy i odrzucił negację, a tym samym pracę żałoby, staje się podmiotem depresyjnym: ,zamyka się nostalgicznie na obiekcie realnym (Rzeczy) swej utraty, którego nie może właściwie utracić, do którego zostaje boleśnie przykuty" (K 49). Podmiot ów, jak pisze Kristeva, nie widzi sensu i wartości swojego języka macierzystego z powodu utraty matki.

Martwy język, którym mówi i w którym zapowiada swe samobójstwo, skrywa pogrzebaną żywcem Rzecz. Aby jej nie zdradzić, nie będzie jej tłumaczył: p o z o s t a n i e z a m u r owan a krypcie niewypowiedzianego uczucia, kontrolowana analnie, bez wyjścia. [K 58-59]

Posługując się pojęciem krypty, Kristeva odwołuje się, oczywiście, do wspomnianych już Nicolasa Abrahama i Márii Török, którzy wprowadzili je do dyskursu medycznego, opisując mechanizm introjekcji i inkorporacji. Ostatecznie autorka Czarnego słońca korzysta raczej z interpretacji André Greena, wyrosłej na gruncie takiej samej obserwacji klinicznej, jakiej dokonali Abraham i Török „psychicznej pustki” (K 59) doświadczanej przed podmiot depresyjny.

W tym miejscu warto przywołać esej Roussel $i$ Wenecja ${ }^{28}$, który rzuca pewne światło na status żałoby autora Gabinetu kolekcjonera ${ }^{29}$. Perec i Harry Mathews

${ }^{27}$ Przytoczony przez Kristevą cytat pochodzi ze szkicu: Z. F r e u d, Die Verneinung. „Revue française de psychanalyse" t. 7 (1934), nr 2.

${ }^{28}$ G. P e r e c, H. M a the w s, Roussel $i$ Wenecja. Zarys geografii melancholicznej. W: Urodziłem się. Eseje (przeł. M. P. M a r k ow s k i).

${ }^{29}$ Uwagę na to zwracało już kilku komentatorów Pereca, przede wszystkim C. B u rge li n (Les Parties de dominos chez Monsieur Lefèvre: Perec avec Freud, Perec contre Freud. Strasbourg 1996), J. P o i r i e r (Les Écrivains français et la psychanalyse 〈1950-2000〉. Maux croisés. Paris 
pozornie bawią się w tym eseju z czytelnikiem, zmyślając od początku do końca historię pięciu kartek-fiszek, jakie Raymond Roussel miał jakoby sporządzić, przygotowując się do napisania sztuki rozgrywającej się w Wenecji. Ale na tym nie poprzestają ${ }^{30}, \mathrm{w}$ swoim szkicu pastiszującym rozprawę naukową podążają bowiem tropem, oczywiście całkowicie fikcyjnego, pobytu pisarza w Wenecji i jego ogromnego zauroczenia młodym chłopcem o imieniu Ascanio, z którego rychłą śmiercią autor Locus solus nie mógł się pogodzić przez całe życie. Aby dowieść, jak bardzo doświadczenie pustki po ukochanym naznaczyło całą twórczość i biografię Roussela, Perec rozmyślnie odniósł się w tekście do sfingowanego artykułu, będącego $\mathrm{w}$ istocie parafrazą i zaszyfrowaną aluzją do słynnego studium Abrahama i Török, gdzie opisali oni m.in. mechanizm inkorporacji, z jego odmową żałoby i złożeniem utraconego obiektu w ,krypcie” psychiki. Twierdzili oni, iż celem inkorporacji jest uniknięcie sytuacji, gdy musiałyby zostać wypowiedziane pewne bolesne słowa, mianowicie te związane z utratą ukochanego przedmiotu, jakiego istnienie było dla podmiotu, dla jego samopoczucia (a właściwie narcyzmu) niezbędne. Perec przytacza następujące ujęcie z fikcyjnego artykułu:

Przedmiot, którego utraty nie chce się uznać, trwa nadal - obok niewyraźnych działań, uczuć i słów - w sekretnym systemie topologicznym, głęboko złożony w krypcie psychiki. Inkorporacja jest więc odmową żałoby $[\ldots]^{31}$.

\section{Znamiennie, jak ów zacytowany fragment skomentował następnie Perec:}

Proszę wybaczyć autorom ten przydługi cytat, trudno jednak było rousselistom oprzeć się pokusie odniesienia tego, co wyżej powiedziane, do Raymonda Roussela, zarówno jego życia [...], jak dzieła [...]. Wydaje się, że inkorporacja jest kluczem do całości dzieła Roussela: wystarczy przypomnieć sobie słynne wrażenie bezruchu i niezmienności, które bierze się stąd, że wszystko, co ma się wydarzyć, już się wydarzyło i miało miejsce, wrażenie, któremu towarzyszy poczucie obojętności, bliskie poczuciu otępienia, jakiego doświadczamy po śmierci ukochanej osoby, zanim jeszcze tę śmierć zaakceptujemy $[\ldots]^{32}$.

Ów passus jest - jak zauważył m.in. Jacques Poirier - tylko nieznacznie zmodyfikowaną wersją znanej pracy Abrahama i Török L'Écorce et le noyau ${ }^{33}$. Perec, swoim zwyczajem, wykorzystuje tu cytat jako maskę, szyfrując to, co naprawdę chce powiedzieć. W omawianym eseju za wyrafinowanym pastiszem, za Rousselowską Wenecją (co znamienne, określaną zawsze jako ,W" ${ }^{34}$ ), do której autor Locus solus miał już nigdy nie powracać po śmierci Ascania, kryje się własne „,W” Pereca, jego własna trauma, a więc śmierć matki w ,epoce W” (W 97), jak nazwał ją w powieści $W$ ou le souvenir d'enfance.

Ciężka depresja, w którą autor La Disparition (Zniknięcie) popadł w roku

2001), a także M a r k o w s k i (Perekreacja). Szkic niniejszy jest do pewnego stopnia rozwinięciem i reinterpretacją owego rozpoznania.

${ }^{30} \mathrm{~W}$ istocie zaś - nie poprzestaje sam Perec; to jego właśnie poproszono o napisanie artykułu o Rousselu w „L'Arc”; rola Mathewsa ograniczała się do podzielenia się z Perekiem pewnym znaleziskiem, które ten następnie włączył do swojego szkicu; o jego genezie zob. m.in. D. C z a j a, $W$ drodze do Wenecji. Podróże imaginacyjne. „Konteksty. Polska Sztuka Ludowa” 2003, nr 1/2.

${ }^{31} \mathrm{P}$ e r e c, M a th e w s, op. cit., s. 252.

32 Ibidem.

${ }^{33}$ P o irie r, op. cit., s. 170.

${ }^{34} \mathrm{~W}$ interpretacji twórczości Pereca trop wenecki jest bardzo istotny - wracam do niego w kolejnej części artykułu. 
1956, ściśle związana - jak pamiętamy - z dotkliwym brakiem czułości, z ,nieobecnością tego, co najważniejsze”, była w dużej części, jeśli nie przede wszystkim, spowodowana tym, co Török i Abraham nazwali odmową introjekcji, nieprzepracowaną żałobą, wynikającą z zamknięcia się ,na obiekcie realnym (Rzeczy) swej utraty, którego [podmiot] nie może właściwie utracić, do którego zostaje boleśnie przykuty" (K 49). Nieprzypadkowo Perec w swojej największej powieści, Życie, instrukcja obstugi, jako motta użyje zdania z Michała Strogowa Jules'a Verne'a: „Regarde de tous tes yeux, regarde! [Patrz, ile tylko sił w oczach, patrz!]” ${ }^{35}$. Tak w utworze Verne'a szyderczo krzyczy tatarski oprawca na chwilę przed wykonaniem wyroku polegającego na pozbawieniu wzroku tytułowego bohatera. Wówczas woła on zrozpaczoną matkę i prosi: „Zostań tu, przede mną. Niech jeszcze zobaczę twoją ukochaną twarz! Niech moje oczy zamkną się patrzą c na c i e b i e!" ${ }^{36}$. Podobnie jak Michał Strogow, choć w innych okolicznościach, Perec inkorporuje ukochaną matkę; to ją ciągle widzi, to - jak powiada narrator tekstu Verne'a - w jej widoku ,zawarło się całe jego życie ${ }^{37}$. Nie mogąc się pogodzić z jej rzeczywistą utratą, unika sytuacji, „w której pewne bolesne słowa musiałyby zostać wypowiedziane"; a owa utracona nieodwracalnie Rzecz spoczywa w krypcie jego psychiki nienazwana, nieprzedstawiona i pokryta milczeniem.

To wszystko prowadzi w nieunikniony sposób do tego, na co szczególnie zwraca uwagę Kristeva w Czarnym słońcu - a więc do powiązania negacji (czyli opierania się dokonaniu żałoby) z mową podmiotu depresyjnego. Odrzucenie negacji w ujęciu tej badaczki jest „runięciem ramy symbolicznej”, a rozpaczliwe przylgnięcie do utraconego obiektu - katastrofą symbolizacji, która, jak Markowski zauważył w komentarzu do pism Kristevej, wyprowadza podmiot poza mowę ${ }^{38}$. Tego właśnie doświadcza Perecowski bohater:

Żyjesz teraz w grozie milczenia. Ale czyż jest ktoś bardziej milczący od ciebie? [C 78]

Jesteś zaledwie zmąconym cieniem, twardym jądrem obojętności, spojrzeniem bez wyrazu umykającym przed innymi spojrzeniami. Masz nieme wargi, zgaszone oczy [...]. [C 21]

Podmiot depresyjny wypada także poza czas, przestaje go odczuwać, zamyka się w sobie, trwając w bezruchu (,udając trupa” 〈K 12〉), dokładnie tak, jak alter ego pisarza, które uczy się ,,przejrzystości, znieruchomienia, nieistnienia” (C 41), u którego ,czas już nie wnika w szczelinę [...] pokoju” (C 36). Perec pisze w Człowieku, który śpi:

Przed tobą, w miarę jak upływa czas, otwiera się życie w bezruchu [...]. Minuta za minutą, godzina za godziną, dzień po dniu, sezon po sezonie, rozpoczyna się coś, co nigdy nie zazna końca: twoje życie roślinne, twoje życie odwołane. [C 37]

Nieomal identyczne słowa wypowiada pisarz w maju $1956 \mathrm{w}$ rozmowie z Ledererem, w czasie podróży do Trouville, dokąd wybiera się z przyjacielem, planując - jak się okaże - popełnić samobójstwo ${ }^{39}$. Bohater utworu Pereca, podob-

${ }^{35}$ P e r e c, Życie, instrukcja obstugi, s. 13.

${ }^{36}$ J. Ver n e, Michał Strogow. Przeł. M. i M. L e śn i ew s c y. Posł. Z. Łu k a w s ki. Katowice 1987, s. 196. Podkreśl. P. J.

37 Ibidem.

${ }_{38}$ M a r kow sk i, Przygoda ciała i znaków, s. XXX.

${ }^{39}$ Zob. B 171. Perec nie pociąga jednak za spust i ostatecznie do niczego nie dochodzi. 
nie jak on sam, nie przystępuje powtórnie do egzaminu, którego nie zdał w sesji czerwcowej, pozostaje w swoim pokoju przy ulicy Saint-Honoré (w tym samym pokoju, pod 203, mieszkał autor powieści), nasłuchując już tylko wybijającego równą godzinę dzwonu kościoła Saint-Roch znajdującego się naprzeciw jego służbówki:

Później, kiedy nadchodzi dzień egzaminu, ty nawet nie wstajesz z łóżka. [C 14]

Nie wypowiesz na czterech, ośmiu lub dwunastu kartkach tego, co umiesz [...]. Ty w każdym razie nie wypowiedziałbyś się na żaden temat, bo nie wiele wiesz, i nic nie $\mathrm{s}$ ą d z i s z. [...] Nie zdobędziesz licencjatu, nigdy nie rozpoczniesz studiów magisterskich. Nie będziesz już studiował. [C 15; podkreśl. P. J.]

Tak samo jak 20-letni Perec, bohater Człowieka, który śpi, czuje się nieudacznikiem, człowiekiem bezsilnym i bezradnym - odkrywa nagle, że „nie umie żyć, że nigdy się nie nauczy" (C 16). Przypomina melancholika z klasycznego opisu Freuda: czuje się podle i nieustannie obnaża to uczucie. To nie świat - jak w przypadku żałoby po utraconej Rzeczy - staje się biedny i pusty, ale to ego okazuje się wypróżnione. Podmiot depresyjny, którym bez wątpienia są zarówno Perec, jak i jego bohater, ,prezentuje nam swoje ego jako nic niewarte, niezdolne do jakichkolwiek osiągnięć oraz nikczemne z moralnego punktu widzenia"40.

Trudno mieć wątpliwości, że Georges Perec, zapisując na odwrocie zdjęcia swojego ojca znamienne słowa (,Il y a quelque chose de pourri dans le royaume de Danemark") odsyłające do Szekspirowskiego dramatu, obnażając się w listach i powtarzając bezustannie: „Jestem złym synem”, szedł przez długi czas właśnie tą drogą.

\section{Pęknięcie}

Nieprzepracowana trauma z dzieciństwa powraca - ukryta pod maską liberackiego eksperymentu - w La Disparition, napisanej dwa lata po Człowieku, który śpi powieści-lipogramie, gdzie Perec, na niemal 320 stronicach, przymusił się do nieużywania litery „," ${ }^{41}$. Trauma znowu nie wyrażona explicite, ale zaszyfrowana na wiele sposobów, to w strukturze utworu, w języku, w pojedynczym znaku typograficznym, to znów w narracji, w pęknięciu, niedopowiedzeniu, ominięciu albo w trudno uchwytnej aluzji. La Disparition jest zapisem okresu, w którym ciągle jeszcze „pewne słowa” nie mogły zostać wypowiedziane, nie mogły przedostać się do języka - tym samym utracona Rzecz albo nie występuje w ogóle, albo tylko za pośrednictwem symptomów ujawniających się przede wszystkim w samym języku.

Zniknięcie (,la disparition”) litery „e" w następstwie ograniczenia przyjętego przez Pereca w tej powieści powoduje nieodwracalne usunięcie, wyrzucenie słów, bez których nie sposób się obejść, bez których mowa nieuchronnie ubożeje, przede wszystkim z powodu wykreślenia prawie wszystkich wyrazów rodzaju żeńskiego ${ }^{42}$. Wypadnięcie „," nie jest zniknięciem po prostu litery, ale najważniejszego elemen-

${ }^{40}$ F r e u d, Żałoba i melancholia, s. 30-31.

${ }^{41}$ Przypomnijmy, że jest to litera najczęściej występująca w języku francuskim.

42 Zob. C. B u rg e li n, Georges Perec. Paris 2002, s. 93. Zob. też J. O 1 c z y k, Perec a liberatura. W zb.: Perec-instrukcja obstugi. Kraków 2010, s. 20. 
tu, „litery-pępowiny”, która - jak słusznie wskazał Claude Burgelin - łączy słowa: „père, mère, je, eux, Perec, Georges [ojciec, matka, ja, oni, Perec, Georges]" 43 .

Tytułowe ,la disparition" to więc, po pierwsze, zniknięcie najistotniejszej litery, symbolizującej utratę tego, co najważniejsze, czyli matki; zawężenie języka, pozbawionego morfemu żeńskiego, oddaje zubożałe życie podmiotu po tym, jak został on pozbawiony ukochanej Rzeczy. Po drugie, to wreszcie usunięcie ,pępowiny" spowijającej i łączącej ze sobą wszystko, co stanowi o tożsamości podmiotu i co w konsekwencji decyduje o jej rozpadzie, o pęknięciu, „dziurze”, którą określić można lejtmotywem twórczości autora Rzeczy ${ }^{44}$. Jednak w „la disparition” wpisane są także inne znaczenia. Słowo to bowiem znalazło się na dokumencie poświadczającym wywiezienie matki Pereca do obozu Drancy, a następnie, 11 II 1943, do Auschwitz. Dokument ów, eufemistycznie określany mianem: Act de disparition, wydany przez francuskie władze w sierpniu 1947, spoczywał zawsze w szufladzie biurka Pereca i był źródłem nadawania przez niego szczególnego znaczenia liczbie 11 (którą autor na różne sposoby wykorzystywał w swoich utworach $)^{45}$. Ostatnie i nie mniej ważne zniknięcie w powieści jest związane z głównym bohaterem: wypada on, wraz z rozdziałem piątym, co spowodowane jest pierwotnym usunięciem $\mathrm{p}$ i ą t e j litery alfabetu. Wszystko to zostaje połączone niezwykłym węzłem, którym jest nazwisko bohatera powieści: Anton Voy ${ }^{46}$.

W galerii postaci powołanych do życia przez Pereca - jak słusznie zauważył Burgelin - Anton Voyl „zajmuje miejsce między dzieckiem z $W$ a człowiekiem, który śpi, nawet jeśli dramatyczność jego historii jest maskowana przez dowcip" ${ }^{47}$. Sieć intertekstualnych odniesień, która spowija całe dzieło Pereca, ujawnia się bowiem także i w tym, że jego główni bohaterowie - zawsze w jakiś sposób obdarzeni losem pisarza - zdają się mierzyć z podobnymi problemami albo wygłaszać słowa korespondujące ze sobą wzajemnie. Anton Voyl jest postacią udręczoną z powodu bezsenności i owianej tajemnicą nieobecności, przypominającą do pewnego stopnia tytułowego bohatera Człowieka, który śpi. Do książki tej zresztą $L a$ Disparition subtelnie nawiązuje, przywołując ,napisaną niegdyś powieść, w której chodziło o pewnego człowieka, który śnił" ${ }^{4}$. Voyl, podobnie jak on, bierze do ręki książkę, by po chwili ją odłożyć, ,nie będąc w stanie uchwycić nic poza niezrozumiałym galimatiasem" ${ }^{49}$; czasami - jak człowiek, który śpi -

ubierał się, wychodził, włóczył się, spędzał noc w barze albo klubie, albo wsiadał do samochodu (chociaż prowadził raczej źle), jeździł losowo, to tu, to tam, podążając za natchnieniem: do Chantilly albo do Aulnay-sous-Bois, do Limours albo Raincy, do Dourdan, do Orly ${ }^{50}$.

Podobnie jak Perec, Voyl mierzy się z pustką, z nieobecnością czegoś, czego

${ }^{43}$ B urge 1 in, Georges Perec, s. 95.

44 Znaczenie tego słowa ujawnia się poprzez częstotliwość jego występowania (a także wyrazów mu pokrewnych); tylko w tekście La Disparition francuskie „le trou” pojawia się kilkadziesiąt razy.

${ }^{45}$ Zwracało na to uwagę wielu znawców Pereca, zob. m.in. Markowski (Perekreacja) i B ellos (op. cit.).

46 Francuskie słowo ,voyelle” oznacza 'samogłoska'. Usunięcie „e” z nazwiska bohatera ma, oczywiście, swój dodatkowy sens.

${ }^{47}$ B u rg e li n, Georges Perec, s. 102.

48 G. P e r e c, La Disparition. Paris 1969, s. 17.

49 Ibidem.

${ }^{50}$ Ibidem, s. 21. 
nie potrafi nazwać, z brakiem dostępu do czegoś, co stanowi w powieści tabu; wie, że istnieje coś, co musi odszukać, a co jest nierozerwalnie związane z jego pochodzeniem; jego udręka polega na niezdolności do reprezentacji tego, co doprowadziło do zniknięcia, co w widoczny sposób łączy się z dezintegracją jego nazwiska: Voyl, zamiast Voyelle. Ocalenie może przyjść tylko wraz z odnalezieniem, wypowiedzeniem, nazwaniem tego, co pozostaje „niewyrażalne" ${ }^{51}$.

Jak pisze Burgelin, w La Disparition pod powierzchnią, która wydaje się zabawą, kryje się

[opowieść] o psychicznym cierpieniu: wszystko wygląda zwyczajnie, a jednak, w głębi, w środku, doświadcza się ,przerażającego” bardziej lub mniej „,chaosu”, który można oznaczyć tylko poprzez pustkę, przez dziurę ${ }^{52}$.

\section{W La Disparition czytamy bowiem:}

Wszystko wygląda normalnie, wszystko będzie wyglądać normalnie, ale za jeden dzień, za osiem dni, za miesiąc, za rok, wszystko zgnije: [...] dziura będzie się powiększać, stopniowo, ogromne zapomnienie, studnia bez dna, napór pustki. Jeden za drugim, zamilkniemy - za zawsze $^{53}$.

Ocalenie nie nastąpi, Voyl z czasem osłabnie, przeraźliwie schudnie, zamilknie, nie mogąc już wydobyć z siebie żadnego dźwięku, i umrze, znikając wraz z piątym rozdziałem powieści. Anton Voyl, podobnie jak wielu bohaterów stworzonych przez Pereca, jest figurą melancholika, człowiekiem, którego psychice brakuje możliwości symbolizacji - i to doprowadza go do rozpaczy. Odwołując się do teorii Kristevej, to, co semiotyczne pozostaje w jego przypadku na trwałe odłączone od tego, co symboliczne. Wobec niewystarczalności wymiaru symbolicznego podmiot znajduje się w sytuacji chaosu, w sytuacji bez wyjścia ${ }^{54}$. Jak stwierdza Kristeva, „Melancholia kończy się więc na asymbolii, na utracie sensu; jeśli nie jestem w stanie już dalej tłumaczyć albo metaforyzować, zamykam usta i umieram" (K 48) - a to właśnie przydarza się bohaterowi La Disparition.

Sam Perec ostatecznie nie podzieli jednak ani losu Voyla, ani tytułowej postaci ze swojego ulubionego opowiadania Kopista Bartleby Hermana Melville'a. Przywoławszy historię Bartleby'ego na końcu Człowieka, który śpi, napisze bowiem: „Nie umarłeś” (C 97), by po chwili powtórzyć: „Nie umarłeś. Nie oszalałeś” (C 100); „Przestań mówić jak człowiek, który śni” (C 101).

\section{Wenecki epizod}

Autor Życia, instrukcji obstugi próbował wyrwać się ze stanu odrętwienia już w czasie terapii z M'Uzanem, komponując pod jego okiem utwór Le Fou (Szaleniec), nigdy nie opublikowany, opisujący życie człowieka pogrążającego się z wolna w szaleństwie - na tym tekście, bez watpienia, wyrósł wydany kilka lat później Człowiek, który śpi ${ }^{55}$. Co istotniejsze, Perec sporządził wtedy krótkie szki-

\footnotetext{
${ }_{51}$ B urge li n, Georges Perec, s. 95.

52 Ibidem, s. 101.

${ }_{53}$ P e r e c, La Disparition, s. 31-32.

${ }^{54} \mathrm{~K} 42$.

${ }^{55}$ Zob. B 176.
} 
ce biograficzne poświęcone swym rodzicom, po nieomal 15 latach i nie bez wahania włączone przez niego do autobiograficznej części powieści $W$ ou le souvenir d'enfance, powstającej w trakcie 4-letniej psychoterapii z Pontalisem ${ }^{56}$. Nieprzypadkowo $W$ otwieraja słowa: „Długo wahałem się, zanim podjąłem opowieść o mojej podróży do W” (W 13). „Długo pozostawałem niezdecydowany” - powtarza raz po raz narrator, dodając, że to, co chce właśnie o p o w i e d z i e ć czytelnikowi, dawniej chciał „trzymać w sekrecie” (W 13). Ale nieco dalej wyzna przecież: ,projekt opisania mojej historii powstał prawie w tym samym czasie, co pomysł pisania"(W 45). Opowiadanie o rodzicach, o dziecięcej traumie było bowiem czymś koniecznym, nieodłączonym, od zawsze nierozerwalnie związanym z zamiarem pisania, ale zarazem stanowiło ogromny „ciężar”, pragnienie, które długo mogło realizować się tylko za pośrednictwem sekretnego systemu napomknień i aluzji.

Uparcie odwlekaną decyzję o rozpoczęciu projektu autobiograficznego o „podróży do W" Perec podjął w drugiej połowie lat sześćdziesiątych XX wieku. Zasadniczą część tego projektu stanowił początkowo tekst L'Arbre (Drzewo), próba pogłębionego opisu drzewa genealogicznego, które Perec tworzył na podstawie rozmów z ciotką Esther i kilkoma krewnymi, sporządzając liczne notatki (skądinąd nie skorzystał $\mathrm{z}$ nich $\mathrm{w}$ pełni $\mathrm{w}$ trakcie pracy nad $W$ ou le souvenir d'enfance). Znamienne, co zdradził na ten temat w liście do Maurice'a Nadeau: „Projekt ten bardzo mnie zajmuje, ale myślę, że trochę boję się w niego tak naprawdę zaangażować" ${ }^{77}$. Kiedy w okresie terapii z Pontalisem przygotowywał już autobiograficzną powieść $W$ ou le souvenir d'enfance, zakrojoną na o wiele szerszą skalę, w podobny sposób zwierzył się Bernardowi Queysanne'owi (reżyserowi adaptacji filmowej Człowieka, który śpi), mówiąc, że to dla niego najtrudniejsza rzecz, jakiej kiedykolwiek się podją $1^{58}$.

Ale czym jest „W”? I w jaki sposób wiąże się ono z dzieciństwem pisarza? Wyjaśnia to sam Perec we wspomnianym liście do Nadeau w lipcu 1969, a więc wtedy, kiedy pomysł powieści jeszcze się nie wyklarował:

[W] Narodziło się z dziecięcego wspomnienia czy, dokładniej, z przywidzenia, które obszernie rozwinąłem około dwunastego, trzynastego roku życia podczas mojej pierwszej psychoterapii. Zupełnie o tym zapomniałem i przypomniałem sobie pewnego wieczoru w Wenecji we wrześniu $1967[\ldots]^{59}$.

W jest wyspą gdzieś na Ziemi Ognistej. Żyje tam rasa atletów [...]. Jest to nieomal wszystko, co sobie przypominam. Ale wiem, że sporo opowiadałem o $\mathrm{W}$ (słownie i przez rysunek) iże, opowiadając o W, mogę dzisiaj opowiedzieć moje dzieciństwo ${ }^{60}$.

Nieomal to samo powtórzy Perec w $W$ ou le souvenir d'enfance:

Poza nieoczekiwanie zrekonstruowanym tytułem, nie miałem prawie żadnych wspomnień z W. Wszystko, co o niej wiedziałem, dałoby się zmieścić w dwu linijkach: życie społeczności zajętej wyłącznie sportem, na wyspie Ziemi Ognistej. [W 17-18]

\footnotetext{
56 Zob. ibidem, s. 174.

${ }^{57}$ G. P e r e c, List do Maurice'a Nadeau. W: Urodzitem się. Eseje, s. 186 (przeł. J. O 1 c z y k).

58 Zob. B 557.

${ }_{59}$ P e r e c, List do Maurice'a Nadeau, s. 189.

${ }^{60}$ Ibidem, s. 190.
} 
Nieprzypadkowo w następnym rozdziale tej książki Perec napisze niemal identycznie o swoim dzieciństwie: „Nie mam wspomnień z dzieciństwa. Moja historia do dwunastego roku życia mniej więcej mieści się w kilku linijkach" (W 17). Już pierwsze słowa utworu („Długo wahałem się, zanim podjąłem opowieść o mojej podróży do W") są więc aluzją do obu jego części. Dzieciństwo Pereca i wyspa W, zamieszkiwana przez społeczeństwo zorganizowane według obozowego, totalitarnego systemu ${ }^{61}$, zostają już na początku związane sekretnym węzłem, którego rozwikłanie uzmysławia czytelnikowi, że to, co nie pojawia się explicite w autobiograficznych partiach książki, można odnaleźć zaszyfrowane w jej części o charakterze fikcyjnym.

Ta ostatnia powstała na kanwie historii wpisanej w serię dziecięcych rysunków, które Perec odnalazł i dzięki którym „odkrył na nowo W”, utrwalając ją w opowieści publikowanej stopniowo w odcinkach w „La Quinzaine littéraire” między 1969 a 1970 rokiem $^{62}$. Dopiero w czasie spotkań z Pontalisem rozpoczął Perec „zszywanie” powieści - części pozornie autobiograficznej (poświęconej traumie z dzieciństwa) i części pozornie fikcyjnej (o Gaspardzie Wincklerze i wyspie W), dążąc do tego, aby te dwie narracje wypracowane w trakcie terapii (pochodzące z dwu okresów życia) prowadzone naprzemiennie, wzajemnie się oświetlały, aby - jak słusznie zauważył Mathews - w pogłosie ich kolizji wywołać „literalnie niewypowiadalny temat" ${ }^{63}$.

Podróż do fikcyjnego $\mathrm{W}$ - o której czytamy w pierwszym rozdziale książki jest więc równocześnie, podjętą z trudem, decyzją o „podróży” do dzieciństwa, którą pisarz odsłania przed czytelnikiem w partiach autobiograficznych; do tego, co aż dotąd „trzymał w sekrecie”, co spoczywało głęboko w „krypcie psychiki”, pokryte milczeniem i nieprzedstawione, do czego, jak już wspomniano, pisarz dawał dostęp wyłącznie za pomocą aluzji, językowych wybiegów albo alegorycznych powieści.

W tym miejscu nie sposób nie przywołać raz jeszcze ze szkicu Roussel $i$ Wenecja weneckiego epizodu, którego znaczenie wzrośnie, jeśli zwróci się uwagę, iż jest on w istocie pogłosem tego, co Perec napisał o Wenecji $\mathrm{w} W$ ou le souvenir d'enfance. To tam właśnie nastąpił przełom, nieoczekiwany powrót do traumy z dzieciństwa, lub - wyrażając to słowami samego autora eseju - długo odwlekana ,podróż do W”. Dariusz Czaja, w innym kontekście, uznał, że Wenecja w wyimaginowanej opowieści Pereca stanowiła dla Roussela przestrzeń rozpoznania samego siebie, a wraz ze śmiercią Ascania przestała dla tytułowego bohatera istnieć, zmieniła się w miejsce niewyrażalne ${ }^{64}$. Czaja wskazał, że duet Perec-Mathews stara się udowodnić, iż Wenecja była dla Roussela „rzeczywistością pierwszą i najważniejszą, miejscem szczególnym jego »sekretnej topologii«" ${ }^{65}$, że podróż

${ }^{61}$ Funkcjonowanie społeczności $\mathrm{W}$ do złudzenia przypomina mechanizmy rządzące rzeczywistością nazistowskich obozów koncentracyjnych, do których Perec czyni aluzję na końcu powieści, zob. W 221-222.

${ }_{62}$ Zob. ibidem, s. 18.

${ }^{63}$ H. M a thew s, Georges Perec. Przeł. A. S o s now ski. „Literatura na Świecie” 1995, nr 11/12, s. 333.

${ }^{64} \mathrm{C}$ z a j a, op. cit., s. 167.

${ }^{65}$ Ibidem, s. 166. 
tam „stanowiła paradygmat i arché wszystkich eskapad"66.; a także, iż po śmierci swego weneckiego ukochanego tytułowy bohater omijał to miasto (zarówno w rzeczywistości, jak i w języku, zgodnie z mechanizmem inkorporacji). Badacz konkluduje ostatecznie, że szkic Roussel $i$ Wenecja jest nie tylko literacką maskaradą, wyrafinowanym żartem i „kpiną z obwieszonej przypisami uczoności” ${ }^{67}$, ale próbą pokazania, że przestrzeń wenecka - oniryczna z jej labiryntową strukturą i zwierciadlaną grą wodnych odbić - stanowi poręczną metaforę literatury ${ }^{68}$. Należałoby jednak dodać, iż ów paradygmat wszystkich „,podróży”, owo miejsce szczególne „sekretnej topologii”, czyli „W” (jak nieprzypadkowo była oznaczana Wenecja przez samego Roussela w jego pięciu kartkach-fiszkach), nie jest w zmyślonej przez Pereca historii niczym innym jak odbiciem jego własnej ,,sekretnej topologii”, jego własnego „W”, które - jak Wenecja dla Roussela - zmieniło się na długo w miejsce niewyrażalne, dokąd autor zdecydował się wreszcie odbyć podróż właśnie w utworze $W$ ou le souvenir d'enfance. „Wenecja stanie się Wojażem, Wojaż stanie się Wenecją, W jednocześnie oznaczać będzie Wenecję i Wojaż” ${ }^{69}$ - pisze Perec w szkicu o Rousselu.

$\mathrm{W}$ powieści $W$ ou le souvenir d'enfance „W" symbolizuje naraz traumatyczne dzieciństwo (śmierć rodziców), totalitarną wyspę (będącą aluzją do nazistowskiej rzeczywistości i życia w obozie) i długo odkładany Wojaż - stanowiący w istocie - wyraźmy to wprost - wywołaną terapią podróż do wnętrza psychiki (do „krypty”), w której zamknięte było to, co pozostawało niewypowiadalne i pokryte milczeniem, a co symbolizuje właśnie „W”. „W” jest jak u Roussela, powtórzmy raz jeszcze, miejscem sekretnej topologii i paradygmatem wszystkich „eskapad”, a więc tym, co stanowiło fundament całego dzieła Pereca.

W tym miejscu nie sposób pozostawić bez odpowiedzi narzucającego się pytania o to, co tak naprawdę sprawiło, że bohater części fikcyjnej, Gaspard Winckler, zdecydował się podjąć wspomnianą podróż do W, by odszukać tam swojego, o c a l on e g o z k a ta str o fy imiennika, cierpiącego na uciążliwą-spowodowaną dziecięcą traumą - przypadłość. Ośmioletniego chłopca-rozbitka, z którym, jak można się domyślić, łączy go znacznie więcej niż tylko imię i nazwisko przyjęte przez bohatera po dezercji z wojska, gdy musiał on ukrywać się pod fałszywą tożsamością. Trudno także - w kontekście kluczowego problemu dochodzenia Pereca do symbolicznego poziomu opracowania żałoby - nie zapytać o to, w jaki sposób ów enigmatyczny epizod z części fikcyjnej i impuls do podjęcia przez bohatera podróży do $\mathrm{W}$, zazębiają się z tym, co mówią nam autobiograficzne ustępy powieści i co wreszcie sugeruje nam samo życie autora Człowieka, który śpi.

I oto tym, kto będzie namawiał Wincklera do udania się w podróż, okaże się zagadkowa postać „o zadziwiająco bliskim głosie” (W 67), Otto Apfelsthal, nieprzypadkowo w pierwszym momencie utożsamiony przez bohatera z lekarzem ${ }^{70}$. Ostatecznie Apfelsthal przedstawi mu się jako pracownik Société de secours aux naufragés, a więc towarzystwa, które powstało po to, aby - na ile to tylko możliwie

\footnotetext{
66 Ibidem.

${ }^{67}$ Ibidem, s. 168

68 Ibidem.

69 P e rec, M a the w s, op. cit., s. 253.

70 Zob. W 21-22.
} 
- udzielać pomocy rozbitkom. Dlatego mimo zaskakująco emocjonalnego zaangażowania w sprawę 8-letniego chłopca, cudem ocalałego z katastrofy, która pochłonęła jego matkę, Caecilię, Apfelsthal podkreśli, że wbrew temu, co można by sądzić, nic go $\mathrm{z}$ tą historią bezpośrednio nie łączy poza powinnością związaną $\mathrm{z}$ wykonywanym zawodem ${ }^{71}$. To tu właśnie znajduje się jeden $\mathrm{z}$ węzłów spajających obie części powieści, a zarazem cały utwór z życiem jego autora. Pozostawione tropy każą bowiem w chłopcu widzieć, oczywiście, osieroconego i cudem ocalałego Pereca - rozbitka zmagającego się z traumą, w Caecilii Winckler - matkę pisarza, Cyrlę-Cecylię Perec, w Apfelstahlu zaś, skłaniającym Wincklera do podróży, Pontalisa, psychoterapeutę Pereca ${ }^{72}$.

Chodząc do Pontalisa, autor $W$ ou le souvenir d'enfance zapadał ,przez cztery lata w [...] czas bez historii, w to nieistniejące miejsce”; pisze o nim: „miało [ono] się stać miejscem mojej historii, mojego wciąż nieobecnego słowa" "73. Leżąc na kozetce, to próbował milczeć, nie mogąc już znieść roztrząsania, to znów mówić, mając wrażenie „rozpoczynania tych samych puzzli”, jakby właśnie w ten sposób, dzięki stopniowemu wyczerpywaniu się potencjalnych kombinacji, miał szansę w końcu pewnego dnia ułożyć obraz, którego szukał ${ }^{74}$. To właśnie w trakcie terapii - zaszyfrowanej w powieści $W$ ou le souvenir d'enfance, a także w puzzlowej intrydze z Życia, instrukcji obstugi ${ }^{75}$ - dokonał się ruch, ,który pozwolił [...] wyjść z tych roztrząsanych i wyczerpujących ćwiczeń, i uzyskać dostęp do mojej [tj. Pereca] historii i własnego głosu [...]”. Perec charakteryzuje go tak: „był on niezwykle powolny: był to ruch samej analizy"76.

W przypadku autora $W$ ou le souvenir d'enfance życie, terapia i pisanie - jako ni mniej, ni więcej tylko terapia - współistnieją ze sobą, wzajemnie się warunkują i oświetlają, stanowiąc nierozerwalny splot, bez którego rozpoznania trudno jest zrozumieć całe właściwie dzieło Pereca. Pisanie rodzi się u niego z pierwotnego pęknięcia, z pustki, z szukania śladów po utraconej obecności. To, co pozostaje

${ }^{71}$ Zob. W 65.

${ }^{72}$ Zwrócił na to uwagę już P o irier (op. cit., s. 173). We wspomnianym już studium poświęconym związkom wybranych pisarzy francuskich z psychoanalizą omawia on, opierając się na teorii Burgelina, także relację Perec-Pontalis i wskazuje, że tak jeden, jak i drugi zaszyfrowali w swoim dziele ową terapię i siebie wzajemnie. W utworach Pereca figurą psychoanalityka są Otto Apfelstahl i Bartlebooth, a także treser zwierząt noszący nazwisko terapeuty, z historii zamkniętej w maleńkim przypisie Życia, instrukcji obsługi. Nieprzypadkowo w opowieści tej udaje się do niego raz w tygodniu chomik-niedobitek, cudem ocalały z katastrofy. Z kolei, jak wykazał P o i ri e r (op. cit., s. 163 n.), u zmarłego niedawno Pontalisa postacie: Simona, Paula czy Pierre'a G., są ni mniej, ni więcej tylko figurą jego słynnego pacjenta, Georges'a Pereca.

${ }_{73}$ P e r e c, Miejsca pewnego podstęu, s. 42.

${ }^{74}$ Zob. ibidem, s. 43.

75 Przenikliwą analizę tej alegorii dali B urge 1 in (Les Parties de dominos chez Monsieur Lefèvre: Perec avec Freud, Perec contre Freud) i P o i r i e r (op. cit.). Dziwaczny kontrakt między Wincklerem i Bartleboothem miałby być w tym ujęciu odbiciem paktu między pacjentem a psychoterapeutą. Bartlebooth bowiem, według P o i r i e r a (op. cit., s. 178), koncentruje w sobie wszystkie wyobrażenia Pereca o Pontalisie; próbuje połączyć ze sobą kawałki układanki przygotowanej przez Wincklera, zmagając się z ich kapryśnością, z zasadzkami, które on zostawił. Bartlebooth zachowuje się więc niczym psychoanalityk i interpretator z klasycznego opisu Freuda, mając za zadanie scalenie biografii pacjenta, przetłumaczenie jej niezrozumiałych fragmentów i wydobycie na jaw nieuświadomionego sensu, owego upragnionego obrazu, o który chodziło Perecowi.

${ }^{76}$ P e r e c, Miejsca pewnego podstęu, s. 45. 
nieprzedstawialne, nie osiągając symbolicznego poziomu opracowania utraty, zaczyna się z wolna przedostawać do języka właśnie za sprawą terapii i pisania jako terapii; tę długą i krętą drogę, pracę nad sobą i nad pamięcią - innymi słowy: pracę żałoby - symbolizuje właśnie „W” i powieść, którą pisarz ukończył nieomal $\mathrm{w}$ tym samym czasie co ostatnią psychoanalizę z Pontalisem.

\section{„Nie jestem sierotą". Podsumowanie}

Czy więc inkorporacja, którą Perec przywołał w szkicu o Rousselu, wraz z metaforą zamkniętej na zawsze krypty (a więc z odmową podjęcia żałoby), jest rzeczywiście - jak sugeruje ów szkic i kilku komentatorów twórczości Pereca jedynym możliwym kluczem pozwalającym odczytać ciemne pasmo Perecowskiego ,życio-dzieła”? Nie wydaje się. Potwierdza to zarówno sama jego biografia, jak i nieliczne, ale niezwykle znamienne uwagi pomieszczone w eseistyce. W Miejscach pewnego podstępu, pisząc o terapii i o ruchu, który pozwolił mu scalić historię i uzyskać dostęp do własnego głosu, Perec podkreśla przecież, że drogę do tego absolutnie konieczną stanowiło obrócenie w proch ,wyrozumowanych kr yjów e k”: „Trzeba było wrócić po swoich śladach, jeszcze raz przejść już raz przebytą drogę, z którą zerwałem wszelkie więzi"77. To właśnie zniszczenie kryjówek, rozkruszenie „krypty” i powrót - w słowach, w opowieści - do „W” spowodowały, że:

pewnego dnia [historia] została mi dana, niespodzianie, zadziwiająco, gwałtownie jak jakieś odtworzone w swej przestrzeni wspomnienie, jak gest, odnalezione ciepło. Owego dnia psychoanalityk zrozumiał to, co miałem mu do powiedzenia, a czego podczas czterech lat słuchania nie rozumiał z tego prostego powodu, że nie powiedziałem mu tego, czego sam sobie nie opowiedziałem $^{78}$.

Słowa, które odnalazł Perec, opowieść, którą podjął, i literatura, którą stworzył, są namacalnym dowodem tego, że w końcu przekroczył pozycję depresyjną - to za ich pomocą uzyskał symboliczny dystans wobec nienazywalnego, umożliwiając introjekcję, a tym samym ,odklejenie się” od Rzeczy. A to właśnie ów mechanizm - jak pamiętamy - umożliwia prawdziwą żałobę. Freudowskie Verneinung jest bowiem w ostatecznym rozrachunku negacją depresji spowodowaną odmową żałoby. Kristeva pisze:

Byt mówiący wydaje się głosić: „Straciłem najważniejszy obiekt, który ostatecznie okazał się moją matką. Ależ nie, odnalazłem ją w znakach, albo raczej nie utraciłem jej (oto negacja) i mogę ją odzyskać w języku, tylko dlatego, że akceptuję utratę". [K 49]

Podmiot, który utracił Rzecz, nie tylko odzyskuje ją na powrót w znakach, ale za ich pomocą - a więc m.in. za pomocą literatury - utrwala ową Rzecz, wynosi ją poza czas, wyrywa śmierci i zapomnieniu. Właśnie to zdaje się mówić Georges Perec w najbardziej przejmującym fragmencie $W$ ou le souvenir d'enfance:

Nie piszę po to, aby powiedzieć, że niczego nie powiem, nie piszę po to, by powiedzieć, że nie mam nic do powiedzenia. Piszę: piszę, ponieważ żyliśmy wspólnie, ponieważ byłem ich częścią, cieniem pośród ich cieni, ciałem przy ich ciele; piszę, ponieważ zostawali we mnie

77 Ibidem.

78 Ibidem. 
niezatarty ślad, ponieważ ów ślad utrwalony jest w moim pisaniu: [...]; pisanie jest wspomnieniem ich śmierci i afirmacją mojego życia. [W 64-65]

To wyłącznie o nich i dla nich jest $W$. „Pour $E$ [Dla E]”, zapisuje w dedykacji Perec, przywołując centralną w La Disparition literę-figurę, k tó r a w ypadła z powieści i którą teraz symbolicznie odnalazł. „Pour eux" - dla nich, „dla moich rodziców” - powie nieco skonsternowanej kuzynce na krótko przed oddaniem książki do druku ${ }^{79}$. Perec mógłby z pewnością powtórzyć słowa, które odnotował Roland Barthes w swoim Dzienniku żałobnym po śmierci matki:

Pisać gwoli pamięci? Nie po to, aby s a m e mu pamiętać, ale po to, by walczyć z rozdarciem zapomnienia anonsując ego się jako absolutne. Z tym-już wkrótce-,,brakiem śladu", nigdzie, w nikim ${ }^{80}$.

Opowiedzenie o „W”, podzielenie się poprzez opowieść ciężarem spoczywającym głęboko w psychice pozwoli Perecowi odnaleźć równowagę. Przestając rozpamiętywać, rozdrapywać $\mathrm{w}$ nieskończoność bolesną ranę, i kompulsywnie zbierać okruchy, które mogłyby mu pomóc zrekonstruować obraz matki, zadowoli się ostatecznie jej ,arbitralnym i schematycznym wyobrażeniem” (W 51).

Usadawiając się w przestrzeni symbolicznej, Perec zdołał scalić tożsamość oraz przynajmniej częściowo zasypać „dziurę”, symbolicznie zagadać katastrofę ${ }^{81}$. Jeśli, jak mówi Kristeva, melancholia i depresja są zaburzeniami symbolicznej relacji ze światem, to ich odwrotność stanowi właśnie sztuka ${ }^{82}$, która ratuje przed autodestrukcją, przed ,przeglądaniem się pustce”. Język bowiem jest „pobudzeniem" i ,wzmocnieniem" (K 42), pisanie - co zanotował Barthes w swoim dzienniku żałobnym - „daje [...] apotropaiczną siłę czy też siłę integracji: in t e g r u j e s i ę prze z ję z y k" ${ }^{83}$. To właśnie poprzez symbol (greckie „symbolon”) zostają zszyte, scalone i przywrócone na swoje miejsce dwie odłamane części, które niegdyś nagle i nieoczekiwanie pękły („Coś pękało, coś pękło”), siejąc spustoszenie w życiu Pereca i jego bohaterów.

Stopniowo, gdy terapia z Pontalisem wchodzi w fazę zstępującą i zbliża się wydanie $W$ ou le souvenir d'enfance, wszystko zaczyna się stabilizować w życiu Pereca, w jego nowym mieszkaniu przy ulicy Linné, gdzie przeprowadza się nieomal w tym samym czasie, pracując nad swoim opus magnum, powieścią Życie, instrukcja obstugi ${ }^{84}$. W ten sposób po wielu latach poniekąd urzeczywistniają się słowa wypowiedziane przez narratora Człowieka, który śpi po wyrwaniu się z odrętwienia i pustki: „Takiego dnia jak ten, może trochę później, może trochę wcześniej, wszystko rozpoczyna się od nowa, wszystko się zaczyna, wszystko dalej trwa" (C 101).

„Nie jestem sierotą" - powie Perec pod koniec życia dziennikarzowi ${ }^{85}$. Pisarz

${ }^{79}$ Zob. B 580.

${ }^{80}$ R. B a r th e s, Dziennik żałobny. 26 października 1977 - 15 września 1979. Tekst przygotowała i opracowała N. Lé g e r. Przeł. K. M. J a k s e n d e r. Wrocław 2013, s. 127.

${ }_{81}$ Zob. M. P. M a r k o w s k i, Życie na miarę literatury. Eseje. Kraków 2009, s. 110.

${ }^{82}$ Zob. Markow ski, Przygoda ciała i znaków, s. XXIX.

${ }_{83}$ B a r th e s, op. cit., s. 189. Podkreśl. P. J.

${ }^{84}$ Zob. B 578-579.

85 J. Z a m or a n o, La Question de l'autoportrait dans ,Un homme qui dort” et „La Dispari- 
odnajdzie swoje schronienie, dom zastępczy w słowach i w literaturze, we wspólnocie wyobrażeniowej, w której nikt nie jest sam, która tak jak nauki humanistyczne w myśli Kristevej powinna być „budowaniem wspólnoty osób mówiących i czujących" ${ }^{86}$. To tam właśnie zapuści ostatecznie korzenie: rodziną

Kiedy odkryłem Stendhala, Jules'a Verne'a, Michela Leirisa, Queneau, stali się oni moją

Czytam mało, ale nieustannie wracam do Flauberta, i Jules'a Verne'a, Roussela i Kafki, Leirisa i Queneau. [W 195]

czytam od nowa książki, które uwielbiam, i uwielbiam książki, do których wracam, za każdym razem z taką samą rozkoszą [...], rozkoszą jakby wreszcie odnalezionego po krewieństwa. [W 195; podkreśl. P. J.]

\begin{abstract}
A b stract
PAWEE JASNOWSKI

(Jagiellonian University of Cracow)

\section{GEORGES PEREC AND THE WORK OF MOURNING}

The article suggests an interpretation of Georges Perec's creativity (given in the light of Bulgarian linguist and Post-Freudian Julia Kristeva) from the psychoanalytical perspective in which the work reveals its hidden face. The author of the article takes notes of psychoanalytical interpretative tropes that Perec left in his work and demonstrates that writing was born from a primal crack and searching the traces for the lost absence. He also points out that the tension between Freudian Verneinung (negation) and Verleugnung (rejection of negation), between mourning and its refusal pierces through the French writer's work and becomes its underground (hidden) series of events. The study is an attempt to nail down that mourning after the loss of a beloved object (Thing) proves possible and that literature was a way leading to it and its final effect.
\end{abstract}

tion". W zb.: Le Cabinet d'amateur. Revue d'études pérecquiennes. Na stronie: http://www.academia. edu/825602/La_question_de_lautoportrait_dans_Un_homme_qui_dort_et_La_Disparition (data dostępu: 24 VI 2013).

${ }^{86}$ M arkow s ki, Przygoda ciała i znaków, s. XLV.

${ }^{87} \mathrm{Z}$ a mor a no, op. cit. 